\title{
Family Health Strategies: Profile/quality of life of people with diabetes
}

\author{
Estratégias Saúde da Família: perfil/qualidade de vida de pessoas com diabetes \\ Estrategias Salud de la Familia: perfil/calidad de vida de personas con diabetes
}

\section{Claudete Moreschi', Claudete Rempel', Daiana Foggiato de Siqueira", Dirce Stein Backes"II, Luis Felipe Pissaia', Magali Teresinha Quevedo Grave'}

' Universidade do Vale do Taquari-UNIVATES. Lajeado, Rio Grande do Sul, Brazil.

"Universidade Regional Integrada do Alto Uruguai e das Missões. Santiago, Rio Grande do Sul, Brazil.

"I' Centro Universitário Franciscano. Santa Maria, Rio Grande do Sul, Brazil.

\section{How to cite this article:}

Moreschi C, Rempel C, Siqueira DF, Backes DS, Pissaia LF, Grave MTQ. Family Health Strategies: Profile/quality of life of people with diabetes. Rev Bras Enferm [Internet]. 2018;71(6):2899-906. DOI: http://dx.doi.org/10.1590/0034-7167-2018-0037

$$
\text { Submission: 01-30-2018 Approval: 03-24-2018 }
$$

\begin{abstract}
Objective: To evaluate the quality of life and to analyze the epidemiological profile of people with diabetes treated in Family Health Strategies. Method: A cross-sectional study carried out with 350 people with diabetes. Results: Most people with diabetes are women, elderly, married, white, with low educational level, retired/pensioners, family income of up to two minimum wages. As the time of people with the disease increases, their quality of life decreases. People with complications from diabetes have a lower quality of life, with a statistically significant difference. Conclusion: Knowledge of the sociodemographic characteristics, clinical evaluation and quality of life of people with diabetes can improve the care process provided to this population.
\end{abstract}

Descriptors: Diabetes Mellitus; Prevalence; Quality of Life; Public Health; Health Management.

\section{RESUMO}

Objetivo: Avaliar a qualidade de vida e analisar o perfil epidemiológico de pessoas com diabetes atendidas em Estratégias Saúde da Família. Método: Estudo transversal, realizado com 350 pessoas com diabetes. Resultados: As pessoas com diabetes, em sua maioria, são mulheres, idosas, casadas, brancas, com baixo nível instrucional, aposentadas/pensionistas, renda familiar de até dois salários mínimos. À medida que aumenta o tempo das pessoas com a doença, diminui a sua qualidade de vida. As pessoas que possuem complicações decorrentes do diabetes possuem uma qualidade de vida menor, com diferença estatística significativa. Conclusão: O conhecimento das características sociodemográficas, de avaliação clínica e da qualidade de vida das pessoas com diabetes pode melhorar o processo de cuidado prestado a esta população.

Descritores: Diabetes Mellitus; Prevalência; Qualidade de Vida; Saúde Pública; Gestão em Saúde.

\section{RESUMEN}

Objetivo: Evaluar la calidad de vida y analizar el perfil epidemiológico de las personas con diabetes atendidas en Estrategias Salud de la Familia. Método: Estudio transversal, realizado con 350 personas con diabetes. Resultados: Las personas con diabetes, en su mayoría, son mujeres, ancianas, casadas, blancas, con bajo nivel instruccional, jubiladas/pensionistas, renta familiar de hasta dos salarios mínimos. A medida que aumenta el tiempo de las personas con la enfermedad, disminuye su calidad de vida. Las personas que tienen complicaciones derivadas de la diabetes tienen una calidad de vida menor, con diferencia estadística significativa. Conclusión: El conocimiento de las características sociodemográficas, de evaluación clínica y de la calidad de vida de las personas con diabetes puede mejorar el proceso de cuidado prestado a esta población.

Descriptores: Diabetes Mellitus; Prevalencia; Calidad de Vida; Salud Pública; Gestión de la Salud. 


\section{INTRODUCTION}

There is currently a significant increase in the prevalence of chronic diseases in Brazil, which increase death rates due to aggravations, especially in the aging population and users of the Brazilian Unified Health System (SUS- Sistema Único de Saúde) ${ }^{(1)}$. Among the most common chronic diseases, Diabetes Mellitus (DM) stands out, whose etiology triggers changes in the social context of the affected person, while requiring changes in lifestyle, and can directly influence the quality of life of the population. It is estimated that the world population with diabetes is 387 million and will reach 471 million in $2035^{(2)}$. A study conducted by the Surveillance System for Risk and Protective Factors for Chronic Diseases by Telephone Survey (VIGITEL- Vigilância de Fatores de Risco e Proteção para Doenças Crônicas por Inquérito Telefônico) found that diabetes affects $8.0 \%$ of the Brazilian adult population ${ }^{(3)}$.

The prevalence of DM in the Brazilian population between the ages of 30 and 69 is $7.6 \%$, whereas over 70 years of age, rates increase to $20 \%$, and $50 \%$ of these individuals are unaware of their diagnosis and $25 \%$ of people with DM do not perform the recommended treatment ${ }^{(4)}$. The treatment of DM is based on preventive and palliative measures, aiming at the reduction and delay of the diseases, through pharmacological treatment and modifications in the lifestyle, as well as encouraging healthy eating and practice of physical exercises ${ }^{(5)}$. The diagnosis of DM reflects directly in the context of the Quality of Life (QoL) of the individual and his/her family group, requiring effective support by Primary Health Care $(\mathrm{PHC})$ in actions that promote health education ${ }^{(6)}$.

In this case, the main source of support for people with DM comes from the Family Health Strategies (FHS), which since its incorporation in Primary Health Care (PHC) have reorganized the traditional curative model, an extended clinical model ${ }^{(7)}$. The FHS team establishes the professional-user link through health education practices and follow-up interventions for people with $\mathrm{DM}^{(8)}$.

\section{OBJECTVE}

To analyze the epidemiological profile and evaluate the quality of life of people with Diabetes Mellitus treated in fourteen Family Health Strategies of a medium-sized municipality of Rio Grande do Sul State/RS.

\section{METHOD}

\section{Ethical aspects}

The ethical procedures were followed, according to Resolution 466 of December 12, 2012. For the accomplishment of the study, the authorization term of the Municipal Health Office (Secretaria Municipal de Saúde) of the municipality was obtained and the project was approved by the Committee of Ethics in Research (Comitê de Ética em Pesquisa).

\section{Design, place of study and period}

This is a cross-sectional population-based study conducted in 14 FHS of a medium-sized municipality in Rio Grande do Sul
State. Data collection occurred between April and September of the year 2015.

\section{Population or sample; inclusion and exclusion criteria}

The study sample consisted of 350 people with DM served by the $14 \mathrm{FHS}$ of the mentioned municipality. Considering that the FHS have approximately the same number of people with DM treated in their coverage territory, 25 participants from each FHS were randomly selected. The sample size of the study (350) was determined considering that in the year 2013, 1,125 people with DM over 18 years were enrolled in the Primary Care Information System - SIAB (Sistema de Informação da Atenção Básica), for a sample with $95 \%$ confidence and $4.4 \%$ error. The following inclusion criteria were established: people with DM, served at the FHS and older than 18 years. Persons who were not in a position to respond to the questionnaires were excluded.

\section{Study protocol}

The data were collected through a questionnaire with sociodemographic variables and clinical evaluation, and also through the application of the Whoqol-bref questionnaire. This is the abbreviated version of the WHOQOL-100 performed by the WHO's QoL group ${ }^{(9)}$. The sociodemographic variables included in the questionnaire were: age, sex, color, occupation (work), schooling level, marital status, religion, family monthly income, and composition of people with DM living in their home. The clinical variables were: disease duration, comorbidities, family history of cardiovascular disease, risk factors, complications and type of treatment.

\section{Analysis of results, and statistics}

The answers of the questionnaires were tabulated in Excel spreadsheet. Descriptive and inferential statistical analysis was performed using the Statistical Package for Social Sciences - SPSS, version 21 . The quantitative variables are described by mean and standard deviation and the qualitative variables, by means of absolute and relative frequency. The results are presented in tables and graphs.

Data from the WHOQOL-Bref questionnaire were analyzed according to the syntax predicted by the study group that carried out the translation of the document. To better understand the QoL of people with DM, the Likert scale was used, divided into five classes of equal size: very bad (0-20); bad (21-40); neither bad nor good (41-60); good (61-80); very good (80-100).

In the inferential statistics, ANOVA (with Tukey pos-hoc test) was performed to compare means between groups of parametric variables, and Kruskal-Wallis for non-parametric variables. Pearson's correlation was used to compare the association between analyzed variables and QoL scores. The level of significance was set at $5 \%$, with significant values of $p \leq 0.05$.

\section{RESULTS}

The data collection sample consisted of 25 people from each of the $14 \mathrm{FHS}$ of the municipality, totaling 350 people with DM. The sociodemographic variables of people with DM who participated in the study will be presented through Table 1 . 
Table 1 - Sociodemographic variables of people with Diabetes Mellitus seen in the Family Health Strategies of a municipality of Rio Grande do Sul, Brazil, 2015

\begin{tabular}{|c|c|c|c|}
\hline Variables & Categories & $\mathbf{n}$ & $\%$ \\
\hline \multirow[t]{2}{*}{ Sex } & Male & 112 & 32.0 \\
\hline & Female & 238 & 68.0 \\
\hline \multirow[t]{7}{*}{ Age } & 0 to 39 & 9 & 2.6 \\
\hline & 40 to 49 & 22 & 6.3 \\
\hline & 50 to 59 & 66 & 18.8 \\
\hline & 60 to 69 & 128 & 36.6 \\
\hline & 70 to 79 & 93 & 26.6 \\
\hline & 80 or over & 32 & 9.1 \\
\hline & Total & 350 & 100 \\
\hline \multirow[t]{4}{*}{ Martital Status } & Single & 21 & 6.0 \\
\hline & Married & 227 & 64.9 \\
\hline & Widow(er) & 81 & 23.1 \\
\hline & Divorced & 21 & 6.0 \\
\hline \multirow[t]{7}{*}{ Schooling } & Illiterate & 41 & 11.7 \\
\hline & Incompleted primary education & 240 & 68.6 \\
\hline & Completed primary education & 14 & 4.0 \\
\hline & Incompleted high school & 33 & 9.4 \\
\hline & Completed high school & 16 & 4.6 \\
\hline & Incompleted higher education & 5 & 1.4 \\
\hline & Completed higher education & 1 & 0.3 \\
\hline \multirow[t]{4}{*}{ Occupation } & Retired or pensioner & 241 & 75.2 \\
\hline & Home & 34 & 9.7 \\
\hline & Autonomous & 14 & 4.0 \\
\hline & Other & 39 & 11.1 \\
\hline \multirow[t]{4}{*}{ Color } & White & 300 & 85.7 \\
\hline & Black & 24 & 6.9 \\
\hline & Brown & 25 & 7.1 \\
\hline & Yellow & 1 & 0.3 \\
\hline \multirow[t]{4}{*}{ Family monthly income } & Up to 1 wage & 76 & 21.7 \\
\hline & Between 1 and 2 wages & 161 & 46.0 \\
\hline & Between 2 and 4 wages & 100 & 28.6 \\
\hline & Between 4 and 10 wages & 13 & 3.7 \\
\hline
\end{tabular}

The variables related to the clinical evaluation of the participants will be elucidated in Table 2 .

The QoL of the 350 people with DM was assessed using the Whoqol-bref questionnaire. Through the analysis of the data, it was verified that the overall mean QoL of the 350 people with DM served at the FHS who participated in the study was $67.6(\mathrm{SD}=18.1)$.

When analyzing the issues in their respective domains, it was verified that in the "physical" domain the mean QoL is 59.9 $(\mathrm{SD}=19.4)$. The "psychological" domain had a mean QoL of 70.1 $(\mathrm{SD}=18.2)$. In the "social relations" domain, mean QoL was 69.4 $(\mathrm{SD}=20.2)$. The "environment" domain had an mean QoL of 70.8
Table 2 - Clinical evaluation variables of persons with Diabetes Mellitus treated in the Family Health Strategies of a municipality in Rio Grande do Sul, Brazil, 2015

\begin{tabular}{|c|c|c|c|}
\hline Variables & Categories & $\mathbf{n}$ & $\%$ \\
\hline \multirow[t]{3}{*}{ Type of Diabetes } & Type 1 & 11 & 3.1 \\
\hline & Type 2 & 336 & 96.0 \\
\hline & Gestational & 3 & 0.9 \\
\hline \multirow[t]{3}{*}{ Family members with DM } & 1 & 258 & 73.7 \\
\hline & 2 & 84 & 24.0 \\
\hline & 3 & 8 & 2.3 \\
\hline \multirow[t]{5}{*}{ Disease duration } & $0-5$ & 142 & 40.6 \\
\hline & $6-10$ & 92 & 26.3 \\
\hline & $11-15$ & 62 & 17.7 \\
\hline & 16 years $>$ & 54 & 15.4 \\
\hline & Total & 350 & 100 \\
\hline \multirow[t]{4}{*}{ Comorbities } & Hypertension & 312 & 89.1 \\
\hline & Dyslipidemia & 230 & 65.7 \\
\hline & Obesity & 171 & 48.9 \\
\hline & Heart's disease & 118 & 33.7 \\
\hline \multirow[t]{5}{*}{ Risk factors } & $\begin{array}{l}\text { Family history of } \\
\text { cardiovascular disease }\end{array}$ & 221 & 63.1 \\
\hline & Smoking & 71 & 20.3 \\
\hline & Inactivity & 224 & 64.0 \\
\hline & Overweight/obesity & 178 & 50.9 \\
\hline & Hypertension & 312 & 89.1 \\
\hline \multirow[t]{2}{*}{ Complications } & Yes & 261 & 74.6 \\
\hline & No & 89 & 25.4 \\
\hline \multirow[t]{4}{*}{ Acute complications } & Hypoglycemia & 164 & 46.9 \\
\hline & Hyperosmolar coma & 31 & 8.9 \\
\hline & Ketoacidosis & 19 & 5.4 \\
\hline & Hyperglycemia & 306 & 87.4 \\
\hline \multirow[t]{5}{*}{ Chronic complications } & Retinopathy & 131 & 37.4 \\
\hline & Neuropathy & 45 & 12.9 \\
\hline & Diabetic foot & 33 & 9.4 \\
\hline & Nephropathy & 30 & 8.6 \\
\hline & Cardiopathy & 25 & 7.1 \\
\hline \multirow[t]{4}{*}{ Type of treatment } & Diet & 1 & 0.3 \\
\hline & $\begin{array}{l}\text { Diet and oral antidiabetic } \\
\text { agents }\end{array}$ & 276 & 78.9 \\
\hline & Diet and insulin & 13 & 3.7 \\
\hline & $\begin{array}{l}\text { Diet, oral antidiabetic } \\
\text { agents and insulin }\end{array}$ & 60 & 17.1 \\
\hline
\end{tabular}

Note: DM - Diabetes Mellitus.

$(\mathrm{SD}=14.7)$. The mean of the physical domain differs statistically from the other domains by the Tukey test $p<0.01$ (Figure 1).

The "physical" domain had neither good nor bad QoL, and the other domains (psychological, social relations and environment) had a good QoL. In the overall mean QoL of people with diabetes, including all domains had a good QoL.

The mean QoL of the 350 people with diabetes assessed, according to the Whoqol-bref questionnaire, was related to age, sex, disease duration, complications, and participation in diabetes education groups. When correlating the mean QoL 
of people with diabetes and age, according to Pearson's correlation, there was a weak, negative and significant correlation $(r=-0.1827 ; p=0.0007)$, showing that according to the age of the people increases, their QoL decreases significantly (weak).

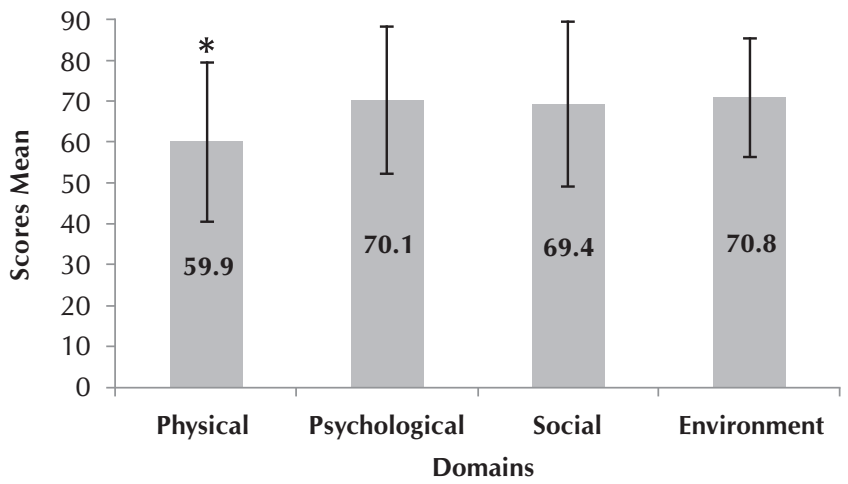

Note: * The asterisked mean differs statistically from the other domains by the Tukey test $p<0.01$.

Figure 1 - Mean and standard deviation of the quality of life scores of people with diabetes participating in the research

Regarding the sex of people with diabetes and the mean of their QoL, in the t test, there was no significant difference between the mean of the women (67.4) and the men (68.0), $(t=-0.3604 ; p=0.7192)$. Regarding the mean $\mathrm{QoL}$ of people with diabetes and the time they have the disease, there was a weak, negative and significant correlation. From this, it is evident that, as the time of people with the disease increases, the QoL decreases $(r=-0.1704 ; p=0.0016)$.

The mean QoL of people with diabetes who have complications, and those who do not have complications differs significantly $(t=3.78, p=0.0002)$. Those with complications have a mean QoL $(65,8)$ lower than those who do not present complications $(72,6)$.

\section{DISCUSSION}

The sociodemographic results of the profile of the people attending the $14 \mathrm{FHS}$ of the studied municipality showed that there is a predominance of people with female DM (68.0\%). Epidemiological studies developed in other States (Pará, São Paulo and Amapá) also show a higher prevalence of DM in women ${ }^{(10-12)}$.

The mean age of this population was 64.4 years old. Boas et al. $(2011)^{(13)}$ found a mean of $59.4(S D=8.02)$ years of age in the DM population studied. Regarding the age group, there was a higher prevalence of participants aged $60-69$ years (36.6\%). A study performed with patients with DM from a Basic Health Unit of Macapá, AP/BR found that the majority are 60 years of age or over ${ }^{(14)}$.

The prevalence of DM, in the majority, affects married individuals $(64.9 \%)$. This result is similar to the study that described the prevalence of DM in users followed by a FHS in the city of João Pessoa/PB, who also found that the majority of respondents were married or in a stable union $(64.3 \%)^{(11)}$. Regarding the schooling level, the majority of the participants in this study have a low level of education, with $68.6 \%$ having incomplete primary education and $11.7 \%$ being illiterate. Similar data were evidenced in a study carried out with the diabetic population in the state of Pernambuco, which found $13.1 \%$ of illiterates and the majority had only primary education ${ }^{(14)}$. Other studies also showed a predominance of low schooling level of patients with $\mathrm{DM}^{(11-12,15-16)}$.

The family income of people with DM is concentrated, for the most part, between 1-2 minimum wages (46.0\%). Almeida and Cardenas (2013) ${ }^{(13)}$ also found that the majority of subjects with DM (55.9\%) had a family income of 1-2 minimum wages. Regarding occupation, the majority of people with DM are retired or pensioners $(75.2 \%)$, a percentage that differs from the study by Boas et al. $(2011)^{(14)}$, who found $41.4 \%$ of the retired or pensioner diabetic population. Another study showed $36.8 \%$ of this population reported being retired or pensioner ${ }^{(12)}$.

The clinical evaluation variables of people with DM, as to the type of DM, of this study, allow the finding that most of the participants have Type 2 DM (96.0\%), followed by Type 1 DM with $3.1 \%$. The Type 1 DM accounts for about $5 \%$ to $10 \%$ of all cases. Already, the Type 2 is more frequent, comprising about $90 \%$ to $95 \%$ of the total cases. When comparing these percentages, it is noticed that, in this study, the percentage of Type 1 $\mathrm{DM}$ is lower and the Type $2 \mathrm{DM}$ is higher than the prevalence predicted by the cited societies. This research does not know why the percentage is different from what is predicted ${ }^{(4)}$.

As for the number of family members who have DM, 24.0\% have another family member who also have this disease, a percentage similar to the finding of the study developed in Colatina-ES, which found that $25.0 \%$ of the participants had first-degree relatives with DM, and $31.0 \%$, second-degree relatives ${ }^{(17)}$. Regarding the time of the disease, a mean of 9.2 years was observed, with a higher prevalence of people with the disease from two to five years. A study conducted in the city of São Paulo, which evaluated the sociodemographic and clinical characteristics of people with Type 2 DM, identified that the mean time to diagnosis of DM was 14.8 years $^{(13)}$. Another study that aimed to describe the prevalence of risk factors and complications of Type 2 DM in users followed at a Family Health Unit in the city of João Pessoa/PB showed that approximately half $(45.7 \%)$ had a diagnosis eight years ago or more ${ }^{(11)}$.

When analyzing comorbidities and risk factors, $89.1 \%$ of people with DM had hypertension, $65.7 \%$ had dyslipidemia, $48.9 \%$ were obese, $64 \%$ were inactive, $63.1 \%$ had family history of cardiovascular disease, 33.7 have some heart disease and $20.3 \%$ are smokers. It is noticed that the majority of participants have hypertension associated with DM. A study that investigated the prevalence of DM in an adult population in the backlands of Pernambuco identified that $68.0 \%$ of diabetics were hypertensive ${ }^{(14)}$. In São Paulo State, a study found a prevalence of $87.7 \%$ of hypertension in people with $\mathrm{DM}^{(13)}$.

It was also observed a predominance of people with dyslipidemic DM. Boas et al. $(2011)^{(13)}$ found that $72.8 \%$ of diabetic individuals had dyslipidemia. Another study developed in Pará State showed that $56.49 \%$ of people with DM had some alteration in their total cholesterol or triglyceride levels ${ }^{(12)}$.

Regarding obesity, it was evidenced that about half of the people with DM in this study are obese (50.9\%). Other studies have indicated that the majority of the population with DM was 
overweight or obese. A study conducted in São Paulo found a prevalence of $46.3 \%$ of the diabetic population with obesity ${ }^{(13)}$.

It was also identified that the majority of people with DM are inactive $(64.0 \%)$. A study that traced the socio-sanitary profile and lifestyle of the hypertensive and/or diabetic population of the city of Teixeiras/MG, found that $67.4 \%$ of inactive individuals $\mathrm{s}^{(15)}$. A study developed with users followed by the FHS in the city of João Pessoa/PB, found that the majority of this population $(71.4 \%)$ was inactive ${ }^{(11)}$.

Regarding smoking, there was a prevalence of $20.3 \%$ smokers among those with DM of this study, a result similar to the study by Cotta et al. (2009)(15), who found $19.6 \%$ of smokers of individuals with DM. Already, Lyra et al. (2010) ${ }^{(14)}$, in a study developed with diabetic subjects, showed that $28.2 \%$ of these were smokers. Smoking is harmful in diabetic complications, especially in cases of nephropathy and macrovascular morbidity and mortality. The cigarette increases the concentrations of total cholesterol and LDL, decreases HDL and increases insulin resistance ${ }^{(18)}$.

The majority $(74.6 \%)$ reported complications due to DM. Among the acute complications, hyperglycemia had a higher percentage with $87.4 \%$ of the population. Hyperglycemia is the primary factor that triggers other complications of $\mathrm{DM}^{(19)}$. Hypoglycemia is an acute complication that can trigger limitations to DM treatment. It can involve high costs in its treatment and prevention, it can also have implications on the quality of life of the individual and his/her family(18).

In 2010, in Brazil, there were 3,741 deaths due to acute DM complications. This figure is equivalent to $6.8 \%$ of the 54,857 DM deaths as the basic cause in the country. Deaths were similarly distributed between coma and ketoacidosis without mention of coma. After corrections and standardization, the mortality rate due to acute complications of DM in the country was 2.45 deaths per 100 thousand inhabitants ${ }^{(20)}$.

With regard to chronic complications, $37.4 \%$ presented retinopathy. Another study found a prevalence of $30.0 \%$ of diabetic retinopathy ${ }^{(11)}$. A study performed by Almeida (2013) ${ }^{(12)}$ detected that $48.5 \%$ presented visual changes. In people with DM, ophthalmologic follow-up should be systematized and rigorously adhered to, so that adequate treatment of retinopathy occurs before irreversible consequences occur. This demonstrates the importance of assistance by public services in the prevention, guidance and treatment of people with DM, making the diagnosis early and preventing the disease $\mathrm{e}^{(4,21)}$.

A study that aimed to determine the prevalence of diabetic peripheral neuropathy in people with Type 2 DM attended at a family medicine unit in Mexico, showed that the overall prevalence of neuropathy in this group of patients was $69 \%{ }^{(22)}$. However, this study found a lower percentage, $12.9 \%$ of the population studied reported having presented the neuropathy complication due to DM. This study found that $8.6 \%$ of people with DM reported having nephropathy. A study developed by Almeida (2013)(12) found that $10.3 \%$ presented kidney alterations.

Another chronic complication investigated was the presence of diabetic foot in the study population $(9.4 \%)$. A study that sought to describe the prevalence of risk factors and complications of Type 2 DM in users accompanied by a Family Health Unit, found that $12.9 \%$ of patients had diabetic foot ${ }^{(11)}$. It is important to implement strategies aimed at favoring diagnosis and treatment in family medicine units, such as the training of patients in self-care with feet and family medical training in foot evaluation. Undoubtedly, timely care will prevent or delay the complications inherent in the condition, reduce high costs and improve patients' quality of life ${ }^{(22)}$.

When considering long-term evolution, DM can cause several consequences, including dysfunction and failure of various organs, especially kidneys, eyes, nerves, heart and blood vessels, as well as being a major population risk factor for cardiovascular disease $^{(11,18)}$. It was found that most of the participants had a family history of cardiovascular disease and $33.7 \%$ of the participants had self-reported heart disease associated with DM. A study that evaluated the adherence to diet and exercise of people with DM found that $52.5 \%$ of the participants had some type of cardiovascular disease ${ }^{(13)}$. There is a direct relationship between blood glucose levels and cardiovascular disease ${ }^{(23)}$.

The data on the type of treatment showed that $78.9 \%$ are on a diet and use oral antidiabetic agents. Most make use of drug treatment $(95.7 \%)$. A study by Rodrigues et al. (2011) $)^{(11)}$ also reported that most of the subjects underwent drug treatment $(95.7 \%)$ and $74.3 \%$ had some kind of diet. Another study showed that all people with DM underwent drug treatment ${ }^{(12)}$. Research developed in Minas Gerais State also showed that DM treatment is basically medicated $(96.6 \%)^{(15)}$.

When assessing the overall mean QoL of people with DM served in the FHS, including all domains, it was found to be good. In relation to the domains evaluated in Whoqol-bref, people with DM presented a better mean of QoL in the "environment" domain and lower mean in the "physical" domain. When discussing the lowest mean found in the "physical" domain, it presented a bad or good QoL. Farias et al. (2014)(24) also found a bad or good QoL in the "physical" domain. The body of a person with DM suffers from disorders inherent in the difficulties of blood flow, especially in the extremities, where ulcerative lesions and amputations are common, as well as the sensation of fatigue and depressive syndromes. Given this, it is perceived that this domain is the most compromised in people affected by the disease, interfering in QoL.

It was found that people with DM served in FHS are satisfied with their environment, with a mean of $70.8(S D=14.7)$. In Alagoas, Farias et al. $(2014)^{(24)}$ found a mean of 54.27. $(S D=13.67)$ in the "environment" domain. In Pelotas/RS, Azevedo et al. $(2013)^{(25)}$ found a mean of $59.0(\mathrm{SD}=14.2)$ in the "environment" domain. The mean QoL in the "environment" domain is higher than the mean found in the literature, evidencing that the people in this study are satisfied with the dimensions assessed in this domain.

Regarding the "psychological" domain, the participants in this study had a good QoL, with a mean of 70.1 (SD=18.2). A study developed by Farias et al. (2014) ${ }^{(24)}$ showed a mean of 61.43 $(\mathrm{SD}=16.71)$ of people with $\mathrm{DM}$ in the "psychological" domain. It is worth mentioning that DM can cause severe changes in population behavior due to the high degree of self-care that is required. These situations can cause suffering in individuals, especially when their level of understanding decreases, as in the case of the elderly, who in some cases have associated degenerative mental diseases ${ }^{(26)}$. 
In the "social relations" domain, a good QoL was found, with a mean of $69.4(S D=20.2)$. Findings similar to these were evidenced in a study carried out in Alagoas, which had a mean of $68.2(\mathrm{SD}=17.47)^{(24)}$. In this sense, another research developed in Pelotas/RS stands out, with a mean of $71.3(\mathrm{SD}=17.7)^{(25)}$. The findings of this study converge with the results of previous studies, indicating that people with DM have a good QoL in the social aspect. It is noteworthy that the majority of participants in this study $(70 \%)$ presented good or very good QoL.

When the evaluation of the domain "social relations" is good, it is possible to affirm that people have good personal relations and perceive that they are socially protected. This demonstrates that, despite the challenges related to coping with the disease, it is possible that people have a good QoL in the domain of social relations. Social protection dignifies the human being, inserting it in a context where it has a function and a meaning to exist, and the community becomes a supporter of good practices ${ }^{(27)}$.

Regarding the sex of the people with diabetes and the mean of their QoL, there was no significant difference between the mean of the women and the men. This result differs from the findings of the Pelotas/RS study by Azevedo et al. (2013) ${ }^{(25)}$, which evaluated the QoL of users with DM and found a significant difference in QoL between women and men, being lower in women.

When correlating the mean QoL of people with diabetes and age, according to Pearson's correlation, there was a weak, negative and significant correlation, showing that, according to the age of the people, it significantly decreases the QoL (weak). A study that evaluated QoL in patients with chronic diseases that seek care in the UBS of the Catholic University of Pelotas/ RS showed that QoL was lower in older people ${ }^{(25)}$, which was in agreement with the findings of this study.

Regarding the mean QoL of people with diabetes and the time they have the disease, there was a weak, negative and significant correlation. It has been shown that, as the time of people with the disease increases, it decreases their QoL.

DM is a chronic disease, therefore, its signs and symptoms accompany the individual in all life cycles. However, the feelings vary according to the acceptance of each person and the adaptation to the proposed treatment. The increase in age brings with it characteristics peculiar to the vital stage, such as dementia and physical weaknesses that influence the autonomy of the individual, requiring the support of a caregiver ${ }^{(18)}$. QoL depends greatly on the perceptions of each individual, and the strenuous health care routine, in some cases, can cause suffering, mainly psychiatric disorders such as anxiety ${ }^{(9)}$.

Another association found was that the mean QoL of people with diabetes who have complications and those who do not have complications differs significantly. It was evidenced that those who presented complications have a mean QoL lower than those who do not present complications. DM is considered a public health problem due to several factors, among them, the significant impairment of QoL due to complications ${ }^{(28)}$.

When reflecting on complications, it is recommended that a professional from the FHS multiprofessional team be able to assume the role of articulator of the educational process within the team, and that this process aims to encourage users to perform self-care and make necessary treatment decisions of the disease.
Health education for people with DM is relevant to controlling the disease, preventing acute and chronic complications, reducing the number of hospitalizations and improving $\mathrm{QoL}^{\left({ }^{(6)}\right.}$.

DM, when well controlled, does not prevent the subject from living a normal day to day life ${ }^{(12)}$. Therefore, the improvement of the QoL is related to a greater satisfaction of the person who has the disease, which involves the treatment adhered, as well as the person's commitment to self-care. The QoL of those with $\mathrm{DM}$ is related to the fact that these individuals need to know and understand their needs in relation to disease control, developing attitudes and beliefs about appropriate management and self-care ${ }^{(28)}$.

\section{Study limitations}

The limitation of the present study is based on the fact that the data collection setting was delimited in a municipality of RS State.

\section{Contributions to Nursing, Health or Public Policy}

It is important to consider sociodemographic and clinical evaluation characteristics of this population that aim to improve the care process provided to people with DM. These data are relevant scientific inputs to reflect and, if necessary, rethink the strategies of health intervention, as well as to outline public policies that meet local and regional health conditions, both individually and collectively.

It is worth noting that the mean QoL of the people with DM served in the FHS and the dimensions that present the best means and the most compromised enables the planning of health promotion actions and the prevention of complications of the individuals with DM attended in Primary Care. Health professionals, such as Nursing, need to be aware of the facets assessed in the "physical", "social", "psychological", and "environment" domains, as these are factors that may interfere with QoL and quality of life. treatment. It is suggested that these variables be worked during the treatment, aiming to contribute to the efficiency of the interventions and to the health promotion of the people with DM attended at the FHS.

\section{CONCLUSION}

The analysis of the epidemiological profile of people with DM attended at the FHS of a city in Rio Grande do Sul State found that the majority are women, elderly, married, white, between 60 and 69 years of age, have a low level of and are retirees or pensioners. It was evidenced that the overall mean QoL of people with DM attended at FHS is good. As for complications, those who report presenting them have a lower QoL than those who do not have complications, with a statistically significant difference. As people's age increases, their QoL decreases significantly. The prevalence found in this study, especially those related to risk factors, comorbidities and complications, indicate the need for preventive interventions that encourage changes in the habits and lifestyle of each individual.

\section{FUNDING}

We thank the Foundation for Research Support of the State of Rio Grande do Sul (FAPERGS), for granting a doctorate scholarship to the first author of the present study. 


\section{REFERENCES}

1. Duncan BB, Chor D, Aquino EML, Bensenor IM, Mill JG, Schmidt MI, et al. Doenças Crônicas Não Transmissíveis no Brasil: prioridade para enfrentamento e investigação. Rev Saúde Pública[Internet]. 2012[cited 2017 May 15];46(1):126-34. Available from: http://www.scielo.br/pdf/rsp/v46s1/17.pdf

2. International Diabetes Federation. IDF Diabetes Atlas[Internet]. 6a ed. Brussels: International Diabetes Federation[Internet].2014[cited 2017 May 11]. Available from: https://www.idf.org/e-library/epidemiology-research/diabetes-atlas.html

3. Brasil. Ministério da Saúde. Secretaria de Vigilância em Saúde. Departamento de Vigilância de Doenças e Agravos não Transmissíveis e Promoção da Saúde. Vigitel Brasil 2014: vigilância de fatores de risco e proteção para doenças crônicas por inquérito telefônico. Brasília: Ministério da Saúde; 2015.

4. Sociedade Brasileira de Diabetes-SBD. Diretrizes da Sociedade Brasileira de Diabetes: 2015-2016. In: Milech A, Oliveira JEP, Vencio S, (Org.). São Paulo: A.C. Farmacêutica[Internet]. 2016[cited 2017 May 11]. Available from: http://www.diabetes.org.br/ profissionais/images/docs/diretrizes-sbd-2015-2016.pdf

5. Silva LAA, Soder RM, Leite MT, Hildebrandt LM, Oliveira IC, Petry L. Gestão da atenção à saúde de usuários com doenças crônicas e degenerativas. Saúde[Internet]. 2016[cited 2017 May 12];42(1):67-74. Available from: https://periodicos.ufsm.br/revistasaude/ article/view/19558

6. Ribeiro KAA, Cristiane M, Figueira S, Jacob LSM. Visita Domiciliária: percepções no espaço da prática. Rev Bras Educ Saúde[Internet]. 2016[cited 2017 May 12];6(1):1-4. Available from: https://www.gvaa.com.br/revista/index.php/REBES/article/view/3819

7. Sousa NPD, Rehem TCMSB, Santos WS, Santos CED. Hospitalizations sensitive to primary health care at a regional hospital in the Federal District. Rev Bras Enferm[Internet]. 2016[cited 2017 May 12];69(1):118-25. Available from: http://www.scielo.br/pdf/ reben/v69n1/en_0034-7167-reben-69-01-0118.pdf

8. Gonçalves J, Sampaio J. O acompanhamento de indicadores de saúde no monitoramento e avaliação da atenção básica: uma experiência no distrito sanitário de João Pessoa/PB. Rev Bras Ciênc Saúde[Internet]. 2016[cited 2017 May 12];19(1):55-60. Available from: http://periodicos.ufpb.br/ojs/index.php/rbcs/article/view/18179

9. Fleck MPA. O instrumento de avaliação de qualidade de vida da OMS (WHOQOL-100): características e perspectivas. Ciênc Saúde Colet[Internet]. 2000[cited 2017 May 12];5(1):33-8. Available from: http://www.scielo.br/pdf/csc/v5n1/7077.pdf

10. Rossaneis MA, Haddad MCFL, Mathias TAF, Marcon SS. Differences in foot self-care and lifestyle between men and women with diabetes mellitus. Rev Latino-Am Enfermagem[Internet]. 2016[cited 2017 May 12];24(1):1-8. Available from: http://www.scielo. br/pdf/rlae/v24/0104-1169-rlae-24-02761.pdf

11. Rodrigues DF, Brito GEG, Sousa NM, Rufino TMS, Carvalho TD. Prevalência de Fatores de Risco e Complicações do Diabetes Mellitus Tipo 2 em Usuários de uma Unidade de Saúde da Família. Rev Bras Ciênc Saúde[Internet]. 2011[cited 2017 May 12];15(1):277-86. Available from: http://periodicos.ufpb.br/index.php/rbcs/article/viewFile/10565/6826

12. Almeida ANF, Cárdenas AMC. Caracterização epidemiológica de pacientes com Diabetes Mellitus tipo 2 de uma Unidade Básica de Saúde de Macapá - AP - Brasil. Rev Ciênc Amazônia. 2013;1(1):74.

13. Boas LCGV, Foss MC, Freitas MCF, Torres HC, Monteiro LZ, Pace AE. Adesão à dieta e ao exercício físico das pessoas com diabetes mellitus. Texto Contexto Enferm[Internet]. 2011[cited 2017 May 12];20(1):272-9. Available from: http://www.scielo.br/pdf/tce/ v20n2/a08v20n2

14. Lyra R, Silva RS, Montenegro RMJ, Matos MVC, Cézar NJB, Silva LM. Prevalência de diabetes melito e fatores associados em população urbana adulta de baixa escolaridade e renda do sertão nordestino brasileiro. Arq Bras Endocrinol Metab[Internet]. 2010[cited 2017 May 12];54(1):560-6. Available from: http://www.scielo.br/pdf/abem/v54n6/09.pdf

15. Cotta RMM, Batista KCS, Reis RS, Souza GADG, Dias G, Castro FAF, et al. Perfil sociossanitário e estilo de vida de hipertensos e/ ou diabéticos, usuários do Programa de Saúde da Família no município de Teixeiras, MG. Ciênc Saúde Colet[Internet]. 2009[cited 2017 May 12];14(1):1251-6. Available from: http://www.scielo.br/pdf/csc/v14n4/a26v14n4.pdf

16. Moreschi C, Rempel C, Carreno I, Silva DS, Pombo CNF, Cano MRL. Prevalence and profile of people with diabetes registered at the primary care information system (SIAB). Rev Bras Promoç Saúde[Internet]. 2015[cited 2017 May 12];28(1):184-90. Available from: http://periodicos.unifor.br/RBPS/article/view/3598/pdf_1

17. Bruno A, Pereira LR, Almeida HS. Avaliação da prevalência de fatores de risco para o desenvolvimento de diabetes mellitus tipo 2 em pacientes da Clínica Unesc Saúde. Demetra[Internet].2015[cited 2014 May 12];9(1):661-80. Available from: http://www.epublicacoes.uerj.br/index.php/demetra/article/viewFile/10659/10924

18. Brasil. Ministério da Saúde. Secretaria de Atenção à Saúde. Departamento de Atenção Básica. Estratégias para o cuidado da pessoa com doença crônica: diabetes mellitus. Brasília: Ministério da Saúde, 2013.

19. Fernandes V, Ramalho J, Santos MJ, Oliveira N, Pereira ML. Diabetes e hiperglicemia: fatores de prognóstico na pneumonia adquirida na comunidade. Rev Port Endocrinol Diabetes Metab[Internet].2015[cited 2018 Mar 15];10(2):133-40. Available from: https://www.sciencedirect.com/science/article/pii/S1646343915000085 
20. Klafke A, Duncan BB, Rosa RS, Moura L, Malta DC, Schmidt MI, et al. Mortalidade por complicações agudas do diabetes melito no Brasil, 2006-2010. Epidemiol Serv Saúde[Internet]. 2014[cited 2017 May 12];23(1):455-62. Available from: http://www.scielo. $\mathrm{br} / \mathrm{pdf} / \mathrm{ress} / \mathrm{v} 23 \mathrm{n} 3 / 1679-4974-$ ress-23-03-00455.pdf

21. Cunha-Vaz J, Ashton P, lezzi R, Ciulla T, Boyer D, Holz FG, et al. Sustained delivery fluocinolone acetonide vitreous implants: longterm benefit in patients with chronic diabetic macular edema. Ophthalmology[Internet]. 2014[cited 2018 May 15];121(10):1892903. Available from: https://www.ncbi.nlm.nih.gov/pubmed/21459216

22. Ibarra RCT, Rocha LJJ, Hernández OR, Nieves RRE, Rafael LJ. Prevalencia de neuropatía periférica en diabéticos tipo 2 en el primer nivel de atención. Rev Med Chile[Internet]. 2012[cited 2017 May 12];140(1):1126-31. Available from: https://scielo.conicyt.cl/ $\mathrm{pdf} / \mathrm{rmc} / \mathrm{v} 140 \mathrm{n} 9 / \mathrm{art04}$.pdf

23. American Diabetes Association. Standards of Medical Care in Diabetes de 2014. Diabetes Care[Internet]. 2014 [cited 2017 May 12];37(Suppl-1):s14-s80. Available from: http://care.diabetesjournals.org/content/37/Supplement_1/S14.long

24. Faria HT, Santos MA, Arrelias CC, Rodrigues FF, Gonela JT, Teixeira CR, et al. Adherence to diabetes mellitus treatments in family health strategy units. Rev Esc Enferm USP[Internet]. 2014[cited 2017 May 12];48(2):257-63. Available from: http://www.scielo.br/ pdf/reeusp/v48n2/0080-6234-reeusp-48-02-257.pdf

25. Azevedo ALS, Silva RA, Tomasi E, Quevedo LA. Chronic diseases and quality of life in primary health care. Cad Saúde Pública[Internet]. 2013[cited 2017 May 12];29(9):1774-82. Available from: http://www.scielo.br/pdf/csp/v29n9/a17v29n9.pdf

26. Radigond AB, Souza RKTD, Cordoni RL, Silva AMR. Assessment of the follow-up of adult patients with arterial hypertension and/or diabetes mellitus by the Family Health Strategy and identification of associated factors in the City of Cambé, Brazil, 2012. Epidemiol Serv Saúde[Internet]. 2016[cited 2017 May 12];25(1):115-26. Available from: http://www.scielo.br/pdf/ress/v25n1/22379622-ress-25-01-00115.pdf

27. Strehlow BR, Dahmer L, Oliveira TB, Fontana RT. Patients' perception of groups on health education of pet health surveillance. Rev Pesqui: Cuid Fundam[Internet]. 2016[cited 2017 May 12];8(2):4243-54. Available from: http://www.seer.unirio.br/index.php/ cuidadofundamental/article/view/4243/pdf_1865

28. Araújo RO, Silva DC, Souto RQ, Marconato AMP, Costa IK, Torres G. Impacto de úlceras venosas na qualidade de vida de indivíduos atendidos na atenção primária. Aquichan[Internet]. 2016[cited 2017 May 12];16(1):56-66. Available from: http://www.scielo.org. co/pdf/aqui/v16n1/v16n1a07.pdf 